\title{
MEDIATING ROLE OF FINTECH ISLAMIC BANKING IN POVERTY REDUCTION DETERMINATIONS: A PERCEPTION STUDY OF SELF-EMPLOYED IN THE NORTHWEST GEOPOLITICAL ZONE, NIGERIA
}

\author{
Kabiru Adamu Kiyawa* and Dr Barjoyai Bin Bardai** \\ * PhD Candidate ** Professor Emeritus \\ Faculty of Administrative Sciences \\ Deparmnent of Islamic Banking and Finance \\ Al-Madinah International University
}

Article DOI: $\underline{\text { https://doi.org/10.36713/epra6339 }}$

\begin{abstract}
The study examines the potential role of fintech-Islamic banking in eradicating poverty in Nigeria among population of selfemployed bankable adults who maintain formal account with the full fledge Islamic banks Jaiz and Tajbank as well as Sterling Plc being conventional bank with Islamic banking Window in Northwest geopolitical zone of Nigeria covering the seven states. The study used a set of questionnaire with six subscales alongside demographic variables having satisfied validity and reliability requirements being important psychometric properties for any data collection instrument. The study take 400 respondents drawn from multistage and purposive sampling techniques in four randomly selected states in the Northwest. The researcher however collected data through on spot data mechanism and were managed and processed using Statistical Package for Social Sciences (SPSS). The Data were analysed using hierarchical regression analysis involving predictor and criterion variables. The findings of the study revealed that financial inclusion and knowledge and patronage of Islamic banking are the direct predictors of poverty reduction whereas interaction of Financial Inclusion and Fintech, Knowledge and Fintech and Culture \& Norms and Fintech are the significant predictors. The study concludes that financial inclusion, knowledge and patronage of Islamic banking, cultural norm individually and interactively have the capacity to eradicate poverty in northern Nigeria if considered during the planning of poverty of reduction programme. It is therefore recommended that practical consideration should be given to these variables when designing poverty eradication initiatives in Nigeria.
\end{abstract}

KEYWORDS: Fintech Islamic banking, poverty reduction, financial inclusion, knowledge and patronage, Northern .Nigeria

\section{INTRODUCTION}

Nigeria is one of the countries with largest population of youth in the world. The country is multiethnic and culturally diverse federation consisting of 36 autonomous states across six geopolitical zones. The geopolitical zones spread across Northern and Southern parts country, and the northern part is Muslim dominated region. The country is situated in western region in the continent with an estimated population of over 200 million people. The country is also blessed with largest natural gas reserves, abundance of natural resources and biggest oil exporter in the continent.

Despite the economic fortune of the country, poverty has been one of the major socioeconomic challenge that confronts Nigeria. Successive and present governments have come up with measures aimed at curtailing the menace of poverty among the populace such as Poverty reduction measures such as empowerment, skill acquisition, Poverty Alleviation Programme (PAP) National Poverty Eradication Programme (NAPEP), National Economic 
Empowerment and Development Strategy (NEEDS) etc yet, poverty remains visible. Records have shown that over 70 million Nigerians are living below the poverty of line of $\$ 2$ per day. Equally, poverty Index showed that there were 86.9 million people living below the poverty line (World Bank, 2018). In a bold move to eradicate poverty, SAP policy was introduced aimed at reducing government participation in the economy and promote private investment. However, SAP ended up aggravating poverty especially among the vulnerable. The National Bureau of Statistics show that $60.9 \%$ of Nigerians in 2010 were living in "absolute poverty" indicating an increase from $54.7 \%$ in 2004 . The NBS (2019) reported that $40.1 \%$ of the population are poor translating into 82.9 million people. Similarly, recent National Bureau of Statistics (NBS, 2019) report on Standard Survey revealed that 82.9 million representing $40.1 \%$ are within the poverty net. These available data indicates the shortcomings of measures adopted to reduce poverty menace thereby raising the demand for more robust approach. It is for this reason, the present paper seeks to employ institutional, individual and cultural attributes as likely measure that could be used in fighting poverty. However, there are paucity of study involving institutional e.g. financial inclusion and fintech Islamic banking; individual factors e.g. gender, education and occupation as well as cultural attributes e.g. cultural norm in relation to poverty reduction. The study therefore examined both direct relationship between institutional, individual and cultural factors with poverty reduction as well as indirect relationship through mediation of fintech-Islamic banking.

\section{REVIEW OF THE RELATED LITERATURE Poverty}

Poverty remains an impediment to the course of promoting growth and development of not only the individuals, but also society and nation as a whole. Poverty is not only characterized by limited resources, health and education, but also lack of power and authority. Wagle (2019) identified three major dimensions of poverty (1) wellbeing which covers income, consumption, and welfare; (2) Capability which focuses on factors other than income, consumption, and welfare but other factors that make individuals unable to derive sufficient human wellbeing such as education, health, and others, and produces stronger impacts on well-being, including on generating incomes necessary to increase consumption of goods and services. (3) Social Exclusion contends that people may be poor, despite having adequate incomes or adequate means for survival i.e., adequate consumption, including food, shelter, and clothing.

In Nigeria, poverty is one major economic challenges facing the country. Records show that the poverty increases especially from 2010 until when it slightly decreased from 2012 through 2014. According to the household survey, the number of people below poverty line increased from 61.1 percent in 2014 to 72.0 percent in 2016 (NBS, 2017). Similarly, data on Human Development Index (HDI) and Capacity Poverty Measure (CPM) show that Nigeria's HDI value for 2018 was 0.534 which makes the country low in human development category making it $158^{\text {th }}$ out of 189 countries and territories. Human Development index covers three elements life expectancy at birth (Longevity); educational attainment; and improvement in standard of living, proxy by per capita income in the measure of poverty. The capacity poverty measure (CPM) focuses on the percentage of the people who lack basic or minimally essential human abilities needed to jump start one from income poverty to a sustainable human development.

It is widely belief that low income is the main problem of the poor, therefore, Karmani (2011) argued that the best way to alleviate poverty is to increase the income of the poor by providing productive employment and to achieve that, productive jobs that lead to higher income are necessary. In support of the argument, Millennium Summit in 2000 considered eradication of poverty and hunger as the first goal of Millennium Development Goals (MDGs) adopted by the United Nations. Following the widespread conviction that poverty can only be reduced if people have decent and productive jobs thereby achieving full and productive employment and decent work for all, including women and young people. However, in the year 2006 a new target was added under MDG number one.

Poverty reduction in the Least Developed Countries (LDCs) requires a "paradigm shift" so that national and international policies should focus on developing productive capacities and creating productive jobs (United Nations Conference on Trade and Development, 2006).

\section{Financial inclusion}

Financial inclusion is one of the best way to accelerate economic growth, reduced poverty and income inequality in a country. Greater financial inclusion is achieved when access to financial assistance, financial information and general financing with ease and minimum cost are achieved in every economic activities, geographical region and segment of the society (Kama \& Adigun, 2013). The major goal of financial inclusion is the promotion of balanced growth through its process of mobilizing savings and investment thereby resulting to efficient resource allocation from the deficit sector to the surplus unit of the society. Financial inclusion therefore guarantees access to financial services, gingers self-development and independence of the poor being a remarkable step 
in linking the poor people with the bigger world (Imboden, 2005).

The introduction of an Islamic financial system has been crucial in facilitating financial inclusion among economic agents, especially in Muslim countries. Islamic financial industry has experienced a massive growth in its assets, from 150 billion to 1.8 trillion dollars recently coupled with deep penetration into developing economies, such as Nigeria (Gelbard, Hussain, Maino, Mu \& Yehoue, 2014). The potency of Islamic finance in the area of financial inclusion, Demirguc-Kunt et al. (2013) argued that Islamic finance remains a viable way of converting financial exclusion in an economy, especially among the less privileged segments of Muslim-dominated economies. Therefore, the introduction of Islamic finance (especially Islamic banks) reduces financial exclusion by accelerating savings and enhancing financial innovation (new financial products) in order to suit the demand from investors, depositors and borrowers to increase participation in formal financial systems (Gheeraet, 2014) and to stimulate competition in the financial sector (Beck, Demirg-Kunt \& Merrouche, 2013).

Islamic banks are money financial intermediaries much like conventional banks but strictly adhere to Islamic law (Syariah principles). Islamic banks are prohibited from speculative activities especially in the form of uncertain and risky businesses and as well as financing unlawful activities. Importantly also, Islamic banks are compelled to give part of their profit as Zakat (Imam \& Kpodar, 2010). The potential of reducing financially excluded increase with introduction of Islamic banking practice in Nigeria. Findings of the study, e.g. Park \& Mercado (2015) indicates that financial inclusion reduces poverty and income inequality among Asian countries. This finding is also consistent with Al-furqan \& Kareem (2013) who found that financial system has strong tendency of bringing transformation to the Nigerian economy through equitable distribution of income and poverty reduction.

\section{Patronage of Islamic Banking}

Patronage of Islamic banking practice determines selection and preferences among customers. Popularity of Islamic banking has continued to grow all over the world as it is currently being practiced in more than 50 countries including Nigeria. Dual banking system (Islamic and conventional banking systems) exist in the most of Muslim dominated countries with exception of few countries e.g. Sudan which operate financial system that is completely built according to Islamic principles with $100 \%$ Islamic banking services.

Today, Islamic banking has become an integral part of global banking and finance industry being an alternative to the interest-based banking system as well as the fastest growing industries having spread all corners of the globe and received wide acceptance by both Muslims and non-Muslims alike. Islamic banking system is a financial intermediation built fair and just financial dealings with the key features that makes it unique such as risk-sharing that encourages entrepreneurship promotion of moral and ethical values as well as sound corporate governance.

Islamic banking system growth in assets size, and locations where its products and services are offered indicate remarkable progress as well as its astounding resilience, especially during the global financial crisis of 2007 through to 2009 (Hasan \& Drid, 2010). The resilience of Islamic banking system makes it a veritable and competitive mode of financing which global society must carry it along. Findings e.g. Hassan (2018) examined consumer bank patronage behavior a pure Islamic banking system in the context of Sudan while Abubakar (2018) assessed customers' engagement/patronage with Islamic banking from plethora of studies conducted over long period of time

\section{Gender}

The division of labour assigns women to domestic work and limits their access to material and social resources and participation in political, economic and social decision-making. Women are at greater risk of poverty because they have relatively limited material assets and also more limited social assets (access to income, goods and services through social connections) and cultural assets (formal education and cultural knowledge). The consequences of this disparity persist throughout a woman's entire life in diverse forms and in different areas and social structures (https://www.globalpolicy.org/).

Household information is the indicator of poverty. Without acknowledging the large gender differences that exist within households. Gender inequalities within family contexts, which cause differentiated access to resources of the domestic group, worsen women's poverty, particularly in poor households. Handa \& Davis (2006) suggests that women are more likely to use resources in ways that improve family well-being, especially that of children. Holvoet (2005) compared the gender effects of two subsidized credit programs in southern India, the integrated rural development program (IRDP) and the Tamil Nadu women's development program (TNWDP) and finds that the decision-making influence of women increases only when credit transfers are made to women. Basic needs like water and sanitation, utilization of health facilities, shelter are affected by education through indirect way and also affects the women's behavior in fertility decisions and family planning (Jeffery \& Basu 1996). 


\section{Education}

Education is one of key socioeconomic indicators. Socioeconomic status (SES) incorporates income in addition to educational attainment, financial security, and subjective perceptions of social status and social class. Socioeconomic status embraces quality of life attributes as well as the opportunities and privileges afforded to people within society. SES remains consistent and reliable predictor of a vast array of outcomes across the life span, including physical and psychological health. SES affects physical and mental health. Educational achievement, poverty and poor health, ultimately affect our society being correlate with low SES. Inequities in health distribution, resource distribution, and quality of life are increasing globally. The association between education and living condition is that investment in education increases the skills and productivity of poor households. It enhances the income level as well as the overall standard of living.

Education enables individuals to determine, what kinds of jobs would be suitable to them, make effective decisions in terms of selection of opportunities that would enable them to bring about improvements in their living conditions and control their living condition which is regarded as one of the main priorities of all individuals. The higher the level of education of the population, the lesser will be the number of poor persons because education imparts knowledge and skills which is supportive in higher wages. The direct effect of education on living style is through increasing the earnings/income or wages.

The strong relationship between level of education and wage has empirically been demonstrated in many societies. People with higher levels of education appear to have, on average, a higher level of productivity. Employers are using learning skills as indicators for estimating the potential productivity of employees. From another perspective, depending on age, people with an advanced level of education, not only begins work at a higher level, but their progress is much faster, which for people with a low degree of education happens later in life. Empirically, Awan, Malik, Sarwar, and Waqas (2011).

\section{Cultural norm}

Poverty generated a set of cultural attitudes, beliefs, values, and practices. The culture of poverty would tend to perpetuate itself over time, even if the structural conditions that originally gave rise to it were to change (Michèle and Small, 2007). Contemporary researchers e.g. Michèle and Small (2007) rarely claim that culture perpetuate rarely itself for multiple generations regardless of structural changes. Relationship between culture and poverty has always been controversial and it is widely belief that the former causes the latter. It is argued that individuals remain poor because of their cultural beliefs and attitudes, and that societies fail to overcome underdevelopment because of their national or collective cultures. According to Michèle and Small (2007), it is generally believe that norms and beliefs can affect patterns of behavior, and that patterns of behavior can be conducive to low socioeconomic attainment.

\section{Occupation}

Expansion of productive and remunerative employment are products of economic growth of a country which potentially brings a high of reduction in poverty. The contribution of the growth process to poverty reduction heavily rely on the rate of economic growth and the ability of the poor to respond to the increasing demand for labour in the more productive categories of employment. Productive employment opportunities contributes substantially to achieving the internationally agreed development goals, such as the Millennium Development Goals Poverty reduction through employment, job-creation occupy a central place in national poverty reduction strategies. Many employment strategies are often related to agricultural and rural development and include using labourintensive agricultural technologies; developing small and medium-size enterprises, and promoting micro projects in rural areas. However, many strategies promote self-employment, non-farm employment in rural areas, targeted employment interventions, microfinance and credit as means of employment generation, skill formation and training. Empirically, Dey (2018) found that non-farm employment in rural areas have significant poverty-reducing effects and human capital constitutes the most potent element in tackling poverty in the target group.

\section{Fintech_Islamic Banking}

The advancement of technology has significantly influence the operations of Islamic banking system. The application of fintech in the Islamic banking system operation improves the efficiency of financial activities and the quality of bank services to its customers. The utilization of fintech in Islamic banking is in line with the growing community needs for online based financial services and the use of internet media for digital data access.

The FINTECH-Islamic banking facilitates easy access to credit facilities to customers thereby increasing their capacity to invest the resources in the economic sectors, thus increasing the tendency of reducing poverty among the populace. The use of FINTECH-Islamic banking has the capacity to improve financial inclusion (access to formal account, savings and loans), increase patronage/knowledge of Islamic banking practice, reduction of gender gaps, encourages the use of one's education and occupational skills as well as assessing the impact of cultural norms in 
relation to poverty reduction. Mehotra (2009) that states access to financial services allows the poor to save from his income in a formal institution which will help in reducing the risks that can affect the poor in the event of any economic shocks or other calamities such as fire and theft in the society.

The conceptual model shows the relationships

\section{The Model}

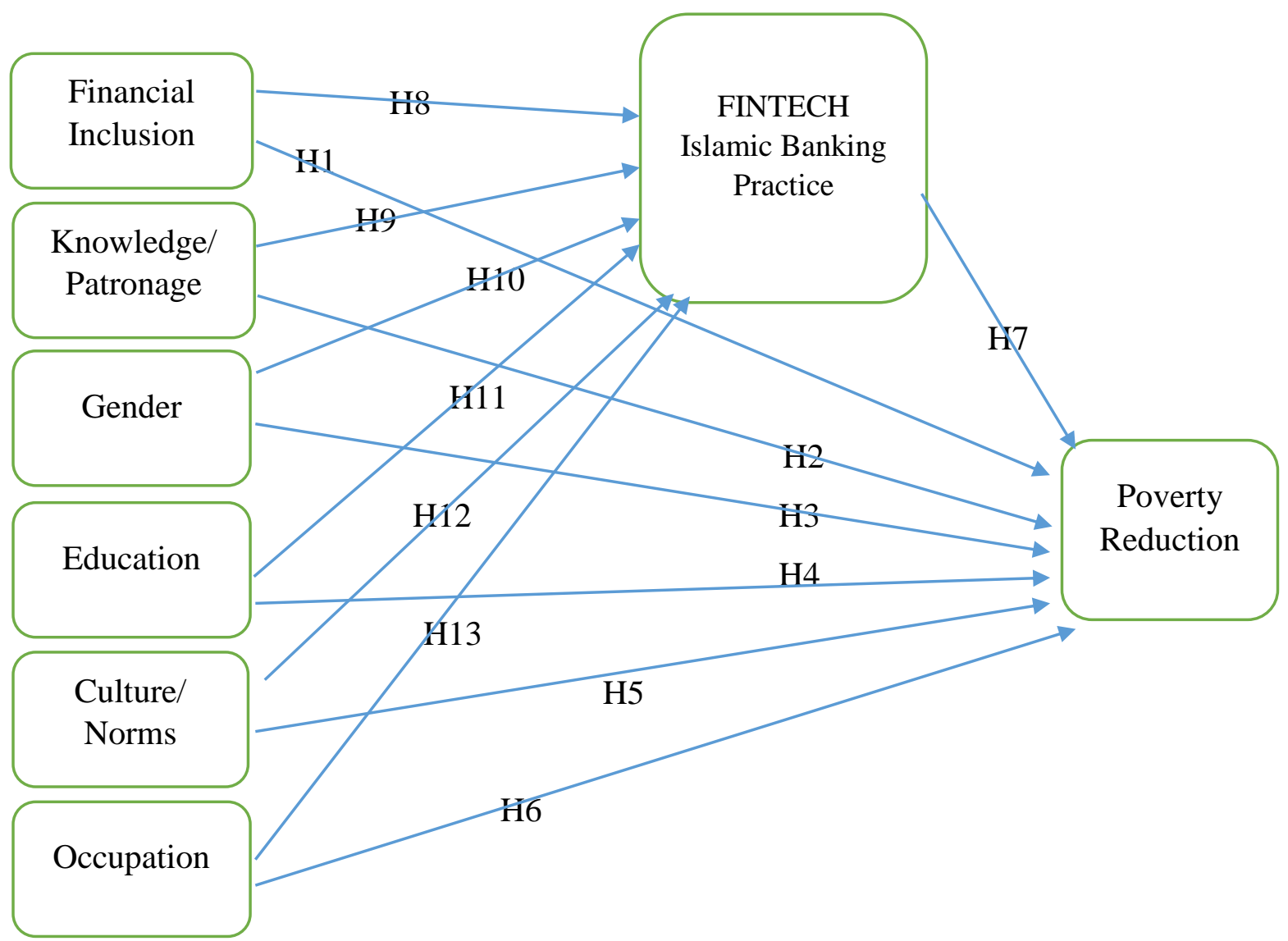

\section{METHODOLOGY}

The study employed survey design as it enables the researcher access to a colossal information bank and to obtain accurate data.

\section{Population and Sample}

The population of the study consists of all bankable self-employed in the Northwest zone of Nigeria. The sample for the study was drawn from the estimated number bankable self-employed individuals that maintain account in a full fledge Islamic banking system or conventional with Islamic windows. The sample was drawn from four randomly selected states comprising of Jigawa, Kano, Kaduna and Katsina. 400 samples were obtained using Yamane's sample size formular.

\section{Sampling Technique}

The study employed multistage sampling technique in which North West geopolitical zone was selected out of the six existing zones, followed by selection of four states out of the seven north western states. The sample respondents were purposive selected from the registered self-employed individuals with Corporate Affairs Commission (CAC) and also maintain a formal account with either full fledge Islamic banks JAIZ and TAJ BANK or conventional with Islamic window-Sterling bank. Finally, the samples were then random selected according the proportion of the registered self-employed respondents from the respective four states- Katsina, Kano, Kaduna and Jigawa who were selected randomly using random numbers..

\section{Data Collection Instrument}

The study used questionnaire as an instrument for data collection. The questionnaire was a researcher developed and it was subjected to regular development process. The instrument contains demographic information e.g. gender, age, education and other 
sections that cover the variables in the study. The instrument was designed to cover the eight constructs such as financial inclusion (6 items), knowledge and patronage of Islamic banking (6 items), education, gender (8 items), cultural norms (8 items), occupation (6 items), fintech-Islamic banking practice (10 items) and poverty reduction (5 items). The instrument was designed based on 5 point Likert scale ranging from strongly disagree down to strongly agree.

In terms of reliability, the coefficient was satisfactory with overall alpha value of 946 while coefficients for the respective variables range from .754 to .863 . However, construct validity was established using Exploratory Factor Analysis (EFA). The indices were found satisfactory above .5 for communalities, rotated component matrix as well as satisfactory variance explained.

\section{Data Analysis}

The data generated from the respondents was managed, processed and analysed using SPSS software.
The data was analysed using hierarchical regression analysis in which direct relationships were first treated from by the interaction effect to determine the predicting capacity of the variables

\section{RESULTS}

Table 1 presents the results for the hierarchical regression analysis with poverty reduction as dependent variable while financial inclusion, knowledge and patronage of Islamic banking, gender, education, cultural norm, occupation as well as interaction of Fin*fintech, K*Fintech, G*Fintech, E*Fintech, $\mathrm{CN} *$ Fintech and $\mathrm{OCC}^{*}$ Fintech as predictor variables. The results show that Financial Inclusion $(B=-1.196, p$ $=.008)$ and cultural norm $(\mathrm{B}=1.406, \mathrm{p}=.000)$ are the significant direct predictors of poverty reduction whereas FI*Fintech $(\mathrm{B}=.332, \mathrm{p}=.003), \mathrm{K}^{*}$ Fintech $(\mathrm{B}$ $=-.025, \mathrm{p}=.054)$ and $\mathrm{CN} *$ Fintech $(\mathrm{B}=-.316, \mathrm{p}=.001)$ are the significant predictors interactively.

Therefore, the regression equation reads as follows:

$\mathrm{Y}=\mathrm{a}_{\mathrm{o}}+\mathrm{b}_{1} \mathrm{X}_{1}+\mathrm{b} 2 \mathrm{X}_{2}+\mathrm{B} 3 \mathrm{X}_{3}+\mathrm{b} 4 \mathrm{X}_{4}+\mathrm{b} 5 \mathrm{X}_{5}+\mathrm{E}$

Hence, $\mathrm{PR}=2.401+\mathrm{b}_{1}(\mathrm{FI})+\mathrm{b}_{2}(\mathrm{CN})+\mathrm{b}_{3}\left(\mathrm{FI}^{*}\right.$ Fintech $)+\mathrm{b}_{4}\left(\mathrm{~K}^{*}\right.$ Fintech $)+\mathrm{b}_{5}(\mathrm{CN} *$ Fintech $)$

Table 1: Coefficients ${ }^{\mathrm{a}}$

\begin{tabular}{|c|c|c|c|c|c|c|}
\hline \multirow{2}{*}{\multicolumn{2}{|c|}{ Model }} & \multicolumn{2}{|c|}{$\begin{array}{l}\text { Unstandardized } \\
\text { Coefficients }\end{array}$} & $\begin{array}{c}\text { Standardized } \\
\text { Coefficients }\end{array}$ & \multirow[t]{2}{*}{$\mathbf{t}$} & \multirow[t]{2}{*}{ Sig. } \\
\hline & & B & Std. Error & Beta & & \\
\hline \multirow{3}{*}{1} & (Constant) & 2.401 & .196 & & 12.233 & .000 \\
\hline & Islamic_BP & .422 & .048 & .411 & 8.880 & .000 \\
\hline & (Constant) & 1.863 & .252 & & 7.399 & .000 \\
\hline \multirow[t]{4}{*}{2} & Islamic_BP & .403 & .047 & .392 & 8.518 & .000 \\
\hline & Cultural_norm & .143 & .043 & .154 & 3.343 & .001 \\
\hline & (Constant) & 1.371 & .309 & & 4.431 & .000 \\
\hline & Islamic_BP & .381 & .048 & .372 & 8.025 & .000 \\
\hline \multirow{7}{*}{3} & Cultural_norm & .125 & .043 & .134 & 2.909 & .004 \\
\hline & Fin_inclusion & .165 & .061 & .126 & 2.694 & .007 \\
\hline & (Constant) & 1.192 & 2.167 & & .550 & .583 \\
\hline & Islamic_BP & .413 & .535 & .402 & .772 & .441 \\
\hline & Cultural_norm & 1.406 & .398 & 1.509 & 3.528 & .000 \\
\hline & Fin_inclusion & -1.196 & .450 & -.910 & -2.656 & .008 \\
\hline & Fin_Fintech & .332 & .113 & 1.763 & 2.939 & .003 \\
\hline \multirow{5}{*}{4} & K_Fintech & -.025 & .013 & -.154 & -1.932 & .054 \\
\hline & G_Fintech & -.005 & .006 & -.045 & -.866 & .387 \\
\hline & E_Fintech & .025 & 017 & 132 & 1.473 & .141 \\
\hline & Occ_Fintech & .011 & .013 & .066 & 847 & .398 \\
\hline & CN_Fintech & -.316 & .098 & -2.014 & -3.224 & .001 \\
\hline
\end{tabular}

\section{DISCUSSIONS}

The findings of the study revealed that financial inclusion, cultural norm, Financial Inclusion and Fintech, Knowledge and Fintech and Culture \& Norm and Fintech are the significant predictors of poverty reduction.Results show that financial inclusion positively and significantly impacts on poverty reduction. The finding of this research is consistent with previous studies (e.g., Jaiswal \& Bhasin, 2015; Mondal, 2015) that suggest that when there is financial inclusion in the rural areas, poor households are likely to use the opportunity to access available financial 
services to invest to increase their level of standard. The study is also consistent with Hussain and Chibuzo (2018) who discovered that there is a significant relationship between the financial inclusion and poverty reduction. The finding of the study proves that financial inclusion has the capacity to reduce poverty as it connotes all initiatives that make formal financial services accessible and affordable, primarily to lowincome people. Generally, financial inclusion has been perceived as a dynamic tool for attaining multidimensional macroeconomic stability, sustainable and inclusive economic growth, employment generation, poverty reduction, and income equality in both developed and developing countries. Study of Omar and Inaba (2020) explains the process through which financial inclusion reduces poverty through interaction term of financial inclusion with GDP growth though effectiveness of financial inclusion depends on different economic factors, scenarios, and conditions.

The finding of the study discovered that financial inclusion has potential of reimbursing the disadvantages group in terms of poverty risk from living in rural areas compared to those living in urban areas. Moreover, financial inclusion can also, to some extent, compensate for a household's lack of asset.

Besides financial inclusion, knowledge and patronage of Islamic banking practice was also found to be important factor that make impact on poverty reduction. The finding of the study is consistent with Dasuki and Abdullahi (2006).Patronage of Islamic banking may likely emanate from respondents' religious inclination, Islamic banking reputation, service quality, satisfaction and factors. The characteristics of patronage include product features, affective perceptions, and knowledge of the product. Affective perceptions toward a particular product and cognitive knowledge about it increase tendency to influence patronage behavior. However, affective perceptions of customers and their level of knowledge about a product make up their relative attitude toward a product. This suggests a strong association between knowledge and perception of a product on one hand and patronage on the other. Patronage may also be expressed in form of customer loyalty, which is defined in terms of willingness and personal initiative for the customer to select the preferred service or product based on their own perceptions. Loyalty has theoretically and empirically been found to be associated with patronage. The knowledge and patronage of Islamic banking among customers enables them to use the available Islamic financial services such as formal account and access to credit facilities that are consistent with faith-based of the customers. The finding of the study revealed that patronizing the Islamic banking services enables the customers to enjoy access to interest free loans being provided by the Islamic banks thereby reducing the incidence of poverty among the populace.

The result for cultural norm shows a positive and significant direct and indirect effects on poverty reduction indicating culture of the society which more incline to Islamic faith belief system is important factor in poverty eradication. The cultural norms encourages individual to engage in all lawful economic activities that one will earn a living and does support hard work and self-reliance.. The finding of the study demonstrates that the use of cultural norm as a factor in poverty reduction has the capacity to reduce poverty among populace. This shows that cultural norm is instrumental to poverty reduction if it's properly explore in fight against poverty menace. The effect of cultural norm on poverty may vary based different existing cultural affiliation of the respondents. All cultures encourage hard work.

Conversely, the findings revealed that knowledge and patronage of Islamic banking, has the capacity to reduce poverty if interacted with fintechIslamic banking Financial inclusion has the tendency to reduce poverty as it enable respondents to have access to formal credit from the banks that operate Islamic banking practices. The study is almost similar to Hussain and Chibuzo (2018) who discovered that microfinance moderate in relationship between financial inclusion and poverty reduction. The findings of the study further revealed that through the intervention of the independent variables the direct contributions could be improved significantly.

\section{CONCLUSIONS}

Poverty is regarded as one of the major problems that course of progression of not only the individuals and communities, but also nation as a whole. The major causes of poverty include among others underemployment, inadequate employment opportunities, natural calamities and disasters, borrowing of loans, health care and medical, geographical isolation, migration, criminal and violent acts and discriminatory treatment against girls and women.

The findings of this study suggest important policy implications regarding poverty for the developing countries. First, Islamic banks should cater for innovative and need based formal financial services that suit all category of individuals in order to attract financially excluded segments of the population through fintech-Islamic banking practice. Doing that provide more equal opportunity to meet the ever changing demand financial services as it varies base on culture, customs, beliefs, and income levels. Islamic financial institutions in collaboration with regulatory authorities should cooperate mutually to develop the 
more relevant and friendly financial services, infrastructure and upgrade the financial services network to cover both rural and urban areas so that more individuals could benefit from such services which are consistent with belief system of the majority.

The significant mediation of fintech-Islamic banking demonstrate that attention is needed to intensify public education and awareness towards the distinctive characteristics of Islamic banking services and how they profitably suit the interest of customers in their financial dealings when it comes to intervention towards poverty reduction. Islamic banks have the potential of being marketed to various segments of customers extending beyond those who are concerned with the legitimacy of the facility from Islamic point of view and those who seek for service quality, convenience and efficient transactions. Translation of research outcome into real practice could be a major milestone in Nigeria due to substantial number of people engulf in poverty trap. The poverty stricken society can be uplifted to a better economic position. Costumer education programmes are therefore crucial as they have the capacity to increase the level of awareness about the unique characteristics of Islamic banking services as they capacity to raise economic status.

\section{REFERENCES}

1. Abubakar, M. (2018). Determinants of customers' cngagement with Islamic Banking" in management of Islamic Finance: Principle, Practice, and Performance. Available https://doi.org/10.1108/S1569. 376720180000019011

2. Kassim, S. I. (2016). The Perceived Influence of Islamic Banking on Financial Inclusion in Nigeria: A Study of Jaiz Customers in Kano: A Pilot Study Journal of Philosophy,

3. Beck, T., Demirg-Kunt, A. \& Merrouche, O. (2013). Islamic vs conventional banking business model, efficiency and stability. Journal of Banking and Finance. Elsevier B. V. 37(2) pp 433-447.

4. Bello, R. A., Toyebi, G.O.A, Balogun, I. O. \& Akanbi, S.B. (2009). Poverty Alleviation Programmes and Economic Development in Nigeria: A Comparative Assessment of Asa and Ilorin West Local Govt. Areas of Kwara State, Nigeria. African Research Review. An International Multi-Disciplinary Journal, Ethiopia, 3 (4).

5. Demi rgüç-kunt, Asli \& leora klapper (2013). Measuring Financial Inclusion: Explaining Variation in Use of Financial Services across and within Countries'.

6. Dey, S. (2018). The Role of Employment Diversification in Reducing Vulnerability to Poverty among Marginal and Small-holder Agricultural Households in India. - The Journal of Applied Economic Research 12 (1), pp. 88-112

7. Gelbard, E., Hussain, M., Maino, R., Mu, Y. \&
Yehoue, E. B. (2014). Islamic Finance in SubSaharan Africa: Status and Prospects.

8. Gheeraet, L. (2014). Does Islamic finance spur banking sector development. Journal of Economic Behaviour and Organization. Elsevier B.V. 103, PP4-20. Doi:10.1016/j.jebo.2014.02.013

9. Hasan, M., \& Dridi, J. (2010). The effects of the global crisis on Islamic and conventional banks: A comparative study. IMF Working Paper, $W P / 10 / 201$

10. Hassan F. M. I (2018). Patronage behavior of Islamic bank's consumers: the importance of Shariah compliance within total Islamic banking system. International Conference on Advances in Business Management and Law (ICABML) (2), available at http://publications.ud.ac.ae/index.php/ICABML$C P$.

11. Iqbal, Z. \& Mirakhor, A. (2012). Financial Inclusion: Islamic Finance Perspective June 2012 Journal of Islamic Business and Management 2(1), 2012 DOI: 10.12816/0004974.

12. Jeffery, R. \& Basu, M.A. (1996). Girls' Schooling, Women's Autonomy and Fertility Change in South Asia. New Delhi: Sage Publications

13. Kama, U., \& Adigun, M. (2013). Financial Inclusion In Nigeria: Issues And Challenges. CENTAL BANK OF NIGERIA, Occasional Paper No. $45,49$.

14. Karnani, A. G (2011). Reducing Poverty through Employment. Innovations 6(2)

15. Mehrotra, Puhazhendhi, Nair, \& Sahoo. (2009). financial inclusion: An overview. Occasionals Paper, Mumbai: Department of Economic Analysis and Research, 244.

16. Michèle, L. \& Small, M. L. (2007). Cultural diversity and poverty eradication. Working Paper 2007-25, Weatherhead Center for International Affairs, Harvard University. Background paper prepared for the World Report on Cultural Diversity, UNESCO.

17. Park \& Mercado (2015)

18. Wagle, U. (2019). Rethinking poverty: definition and measurement. Retrieved on $6^{\text {th }}$ July, 2020 from https://doi.org/10.1111/issj.12192 